\title{
Phytochemical Profile and Antibacterial and Antioxidant Activities of Medicinal Plants Used by Aboriginal People of New South Wales, Australia
}

\author{
Kaisarun Akter, ${ }^{1}$ Emma C. Barnes, ${ }^{1}$ Joseph J. Brophy, ${ }^{2}$ David Harrington, ${ }^{1}$ \\ Yaegl Community Elders, ${ }^{3}$ Subramanyam R. Vemulpad, ${ }^{1}$ and Joanne F. Jamie ${ }^{1}$ \\ ${ }^{1}$ Indigenous Bioresources Research Group, Faculty of Science and Engineering, Macquarie University, North Ryde, \\ Sydney, NSW 2109, Australia \\ ${ }^{2}$ School of Chemistry, Faculty of Science, University of New South Wales, Sydney, NSW 2052, Australia \\ ${ }^{3}$ Yaegl Local Aboriginal Land Council, Maclean, NSW 2463, Australia
}

Correspondence should be addressed to Subramanyam R. Vemulpad; subramanyam.vemulpad@mq.edu.au and Joanne F. Jamie; joanne.jamie@mq.edu.au

Received 29 January 2016; Accepted 29 June 2016

Academic Editor: Laura De Martino

Copyright ( 2016 Kaisarun Akter et al. This is an open access article distributed under the Creative Commons Attribution License, which permits unrestricted use, distribution, and reproduction in any medium, provided the original work is properly cited.

\begin{abstract}
Aboriginal people of Australia possess a rich knowledge on the use of medicinal plants for the treatment of sores, wounds, and skin infections, ailments which impose a high global disease burden and require effective treatments. The antibacterial and antioxidant activities and phytochemical contents of extracts, obtained from eight medicinal plants used by Aboriginal people of New South Wales, Australia, for the treatment of skin related ailments, were assessed to add value to and provide an evidence-base for their traditional uses. Extracts of Acacia implexa, Acacia falcata, Cassytha glabella, Eucalyptus haemastoma, Smilax glyciphylla, Sterculia quadrifida, and Syncarpia glomulifera were evaluated. All extracts except that of S. quadrifida showed activity against sensitive and multidrug resistant strains of Staphylococcus aureus with minimum inhibitory concentration values ranging from 7.81 to $1000 \mu \mathrm{g} / \mathrm{mL}$. The sap of E. haemastoma and bark of A. implexa possessed high total phenolic contents (TPC) and strong DPPH radical scavenging abilities. A positive correlation was observed between TPC and free radical scavenging ability. GC-MS analysis of the $n$-hexane extract of $S$. glomulifera identified known antimicrobial compounds. Together, these results support the traditional uses of the examined plants for the treatment of skin related ailments and infections by Aboriginal people of New South Wales, Australia.
\end{abstract}

\section{Introduction}

The Aboriginal people of Australia have over 40,000 years of knowledge of flora and fauna as sources of food, healing agents, and other resources [1]. Numerous plant species have been utilised as traditional medicines by Australian Aboriginal people [2], in particular for the topical treatment of sores, wounds, and skin infections, ailments which are especially common in Aboriginal communities [3]. For example, a retrospective review of the medical records of 99 children attending a primary healthcare centre in a remote area of the East Arnhem region in the Northern Territory of Australia found that by one year of age, $68 \%$ and $82 \%$ of the children had presented with their first case of scabies or streptococcal pyoderma (impetigo), respectively [4]. The use of plants for the treatment of such ailments indicates that they may provide extracts or pure compounds with antimicrobial or wound healing properties. However, to date, only a limited number of these plants have been investigated for their biological activities and/or chemical constituents $[2,3]$.

Problems associated with skin related infectious diseases and chronic wounds are not limited to Indigenous communities but are serious global threats [5]. It is well known that infection rates have increased and antibiotic resistance has become a growing therapeutic problem $[6,7]$. In combination with bacteria being one of the most important 
factors responsible for skin infection and delayed wound healing [8], low antioxidant levels are also associated with such diseases [9].

As part of a collaborative research program initiated upon the request of Yaegl Aboriginal people of Northern New South Wales (NSW) to help with conserving, analysing, and developing their medicinal knowledge for ecotourism and healthcare, we have ethnobotanically documented thirtytwo Yaegl medicinal plants [10] and conducted preliminary biological and phytochemical studies [11, 12]. To extend this research program, we conducted a literature review in 2012 of 128 plants used as traditional medicines across NSW with regard to their distribution and habitat, documented traditional use, biological activity, and phytochemistry [3]. This review identified significant scope for further biological and chemical investigations of medicinal plants of NSW to add to the growing understanding of this resource. It also highlighted the paucity of community specific details in the published literature.

In recognition of the potential of traditional medicines for topical treatment of skin related ailments, a further literature review of medicinal plants documented in the Yaegl study [10] and NSW review [3] for these applications was conducted. This identified three plants, Hibbertia scandens (leaves), Smilax glyciphylla (leaves), and Syncarpia glomulifera (leaves), used by the Yaegl Aboriginal community, and five NSW plants, namely, Acacia falcata (bark), Acacia implexa (bark), Cassytha glabella (whole plant), Eucalyptus haemastoma (sap), and Sterculia quadrifida (leaves), for which limited or no biological and/or phytochemical studies had been undertaken. Acacia implexa (bark), Acacia falcata (bark), Eucalyptus haemastoma (sap), and Sterculia quadrifida (leaves) are reported to be used for the treatment of sores and skin complaints [3,13], Hibbertia scandens (leaves) is used for the treatment of sores and rashes [10], Cassytha glabella (whole plant) is used for bathing (topically) to relieve pain and Smilax glyciphylla (leaves) to clear skin problems, aches, and pains $[3,10,13]$, and sap and ash from the leaves of Syncarpia glomulifera are used as an antiseptic [11] (Table 1). C. glabella has been found to be a source of quercetin and anthocyanins [14], but no biological studies have been undertaken on this plant. S. glyciphylla possesses antioxidant activity and phenolic compounds have been isolated from its leaves [15]. S. quadrifida is reported to have moderate antifungal activity but there were no reports for phytochemical studies [16]. An antibacterial triterpenoid was isolated from the bark of S. glomulifera [17], as well as eucalyptin and 8-desmethyleucalyptin from its leaf wax [18]. The identification of essential oils from the leaves of S. glomulifera has also been undertaken [19]; however, there are no reports on the biological activity of extracts of its leaves. A. falcata, A. implexa, H. scandens, and E. haemastoma have had no reports for either biological or phytochemical studies.

In this study, $70 \%$ aqueous ethanolic extracts were prepared from the selected plants. The antibacterial activities of these extracts were determined using the MTT microdilution assay method and antioxidant activity by DPPH free radical scavenging, ABTS radical scavenging activity, and ferric reducing antioxidant power (FRAP) assay methods. Qualitative phytochemical screening and the quantification of the total phenolic, flavonoid, and tannin contents of the extracts were also undertaken. Furthermore, the $n$-hexane extract of S. glomulifera was chosen for gas chromatographymass spectroscopy (GC-MS) analysis, which led to the identification of several known antimicrobial and antioxidant compounds.

\section{Materials and Methods}

2.1. Ethics. The research with the Yaegl Aboriginal Elders was approved by the Human Research Ethics Committee at Macquarie University (HE27 JUL2007-R05356 and 5201200763). It was conducted under the framework of best ethical practice, working in partnership with Indigenous people [62], and was governed by a cooperative research agreement with the Yaegl Community [63].

2.2. Collection of Plant Material. The leaves of Syncarpia glomulifera, Hibbertia scandens, and Smilax glyciphylla, bark of Acacia implexa and Acacia falcata, sap of Eucalyptus haemastoma, and whole plant of Cassytha glabella were collected and identified by plant taxonomist David Harrington. The leaves of Sterculia quadrifida were collected by botanist Robert Johnstone and identified by plant taxonomist Alison Downing. The plant samples of $A$. implexa and $A$. falcata were collected from Mulgoa, NSW; the samples of C. glabella and S. glyciphylla from Macquarie University's NSW Ecology Reserve; the samples of E. haemastoma, H. scandens, and S. glomulifera from Macquarie University's gardens; and $S$. quadrifida from Cudgen Nature Reserve, North Coast NSW. The GPS locations of the collection sites were recorded. Voucher specimens were deposited within the IBRG Herbarium, registered with the Index Herbariorum, New York, except for S. quadrifida which was lodged with the Macquarie University Herbarium. The collected plant materials (except the sap of E. haemastoma) were thoroughly washed under running tap water and air-dried at room temperature. The dried plant materials were ground into a fine powder using a coffee grinder. The hardened sap of E. haemastoma was collected by scraping it from the trunk of the tree; the sap was then directly extracted with solvent.

2.3. Preparation of Extracts. The powdered plant samples of A. implexa, $H$. scandens, $S$. quadrifida and S. glomulifera (0.7 L $\times 3,24 \mathrm{~h}$ intervals), A. falcata $(0.6 \mathrm{~L} \times 3,24 \mathrm{~h}$ intervals), C. glabella and S. glyciphylla $(0.5 \mathrm{~L} \times 3,24 \mathrm{~h}$ intervals $)$, and sap of E. haemastoma $(0.2 \mathrm{~L} \times 3,24 \mathrm{~h}$ intervals $)$ were each extracted with $70 \%$ aqueous ethanol at room temperature with occasional shaking (for plant sample amounts see Table 1). The extracts were filtered under vacuum through Whatman filter paper No. 1; then the solvent removed by evaporation using a Buchi rotary evaporator at $38^{\circ} \mathrm{C}$ before the crude samples were freeze-dried on a CHRIST alpha 14 LD plus (UK) freeze dryer. The quantities of the crude extracts obtained are given in Table 1. 


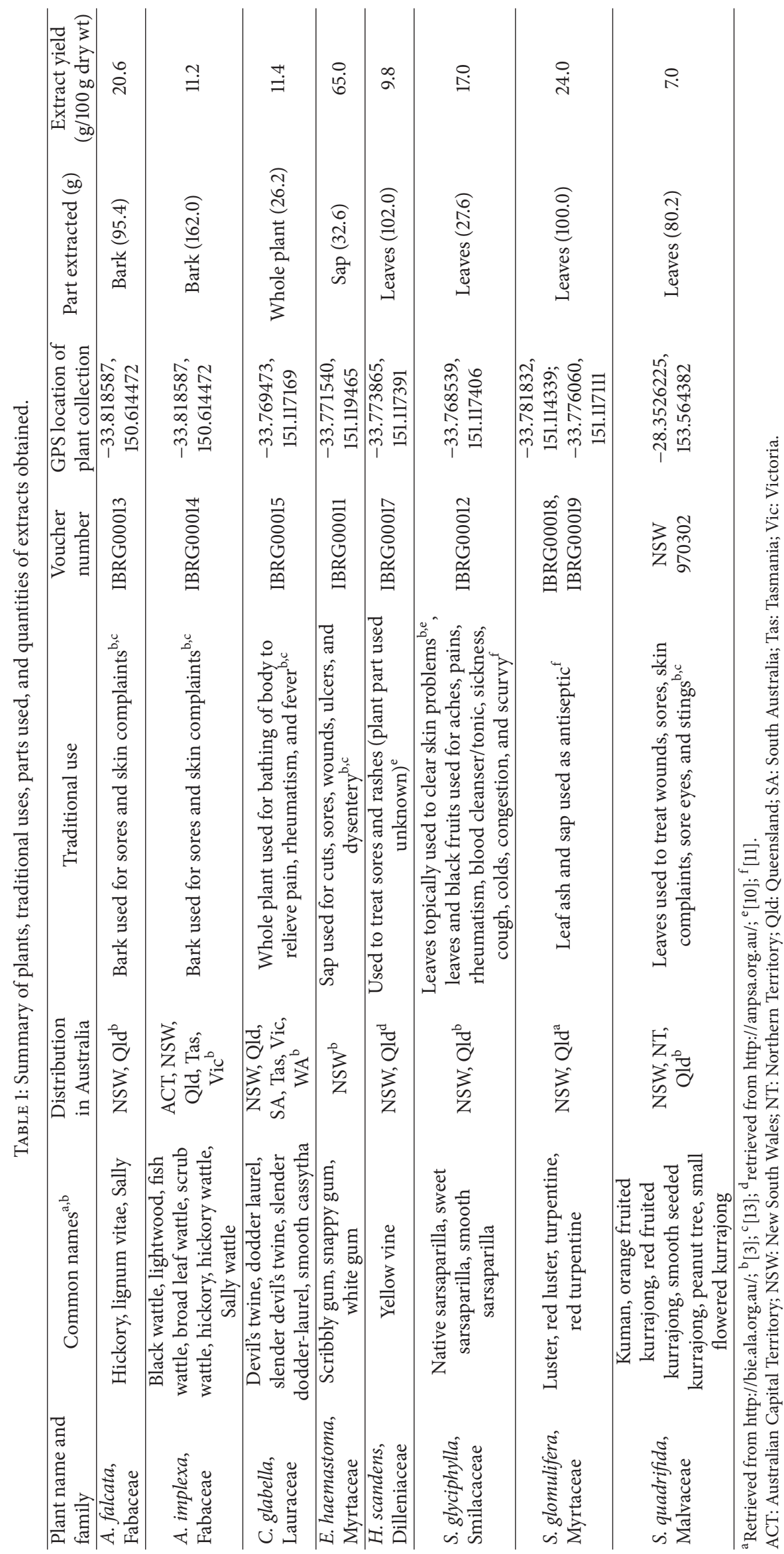


2.4. Chemicals. All chemicals were of the highest purity $(\geq 99.0 \%)$. Ferric chloride, Dragendorff's reagent, magnesium metal strips, gallic acid, ascorbic acid, catechin, FolinCiocalteu reagent, sodium carbonate, vanillin, aluminium chloride, phosphate buffer, 2,2-diphenyl-1-picrylhydrazyl (DPPH), 2,2' -azinobis-(3-ethylbenzothiazoline-6-sulfonic acid) (ABTS), 2,4,6-tripyridyl-s-triazine (TPTZ), 6-hydroxy2,5,7,8-tetramethylchroman-2-carboxylic acid (Trolox), potassium persulfate, and ferric trichloride hexahydrate $\left(\mathrm{FeCl}_{3} \cdot 6 \mathrm{H}_{2} \mathrm{O}\right)$ were all purchased from Sigma Aldrich, USA. Hydrochloric acid ( $\mathrm{HCl})$, methanol, chloroform, 98\% sulfuric acid, and glacial acetic acid were all analytical grade and purchased from Merck, Germany.

2.5. Phytochemical Analysis. Phytochemical screenings for alkaloids, flavonoids, steroids, terpenoids, tannins, saponins, and anthraquinones were conducted in accordance with published methods [64-66]. For alkaloids, $0.02 \mathrm{~g}$ of extract was stirred with $2 \mathrm{~mL}$ of $1 \% \mathrm{HCl}$ on a steam bath and then filtered. A few drops of Dragendorff's reagent was used to treat $1 \mathrm{~mL}$ of filtrate. An orange precipitate indicated the presence of alkaloids. For flavonoids, $0.02 \mathrm{~g}$ of extract was dissolved in $1 \mathrm{~mL}$ of methanol. A chip of magnesium metal was added to the solution followed by the addition of a few drops of $11.6 \mathrm{M} \mathrm{HCl}$. The occurrence of a magenta colour indicated the presence of flavonoids. For steroids, $0.02 \mathrm{~g}$ of extract was dissolved in $2 \mathrm{~mL}$ of chloroform and filtered (using Whatman No. 1 filter paper). $98 \% \mathrm{H}_{2} \mathrm{SO}_{4}$ was carefully added to the filtrate. A reddish brown colour at the interface indicated the presence of steroids. For terpenoids, $0.02 \mathrm{~g}$ of extract was dissolved in $2 \mathrm{~mL}$ of methanol and filtered. Acetic anhydride $(1 \mathrm{~mL})$ was added to the filtrate and then $2 \mathrm{~mL}$ of concentrated $\mathrm{H}_{2} \mathrm{SO}_{4}$ was added carefully to the side of the tube. Formation of a reddish brown colour at the interface indicated the presence of terpenoids. For saponins, the frothing test was used. About $0.5 \mathrm{~g}$ of extract was mixed with $15 \mathrm{~mL}$ of Milli-Q water and shaken vigorously for 5 minutes. The formation of a stable froth indicated the presence of saponins. For tannins, $0.02 \mathrm{~g}$ of extract was dissolved in $2 \mathrm{~mL}$ of Milli-Q water and filtered. A few drops of $1 \%$ ferric chloride solution were added to the filtrate. Formation of a blue colour indicated the presence of tannins. Anthraquinone glycosides were detected using the Borntrager's test after hydrolysis of the extract with $10 \%$ hydrochloric acid. Chloroform was added to the hydrolysate and the contents were shaken and treated with $10 \%$ ammonia solution. The development of a pink colour indicated the presence of anthraquinone glycosides [67].

2.6. Total Phenolic Content of Extracts. The total phenolic content was determined using Folin-Ciocalteu reagent as reported by Muanda et al. [68] with slight modification. The samples were prepared at a concentration of $1.25 \mathrm{mg} / \mathrm{mL}$ in methanol. To $250 \mu \mathrm{L}$ of extract $(1.25 \mathrm{mg} / \mathrm{mL}$ in methanol), $3.5 \mathrm{~mL}$ of distilled water and $250 \mu \mathrm{L}$ of Folin-Ciocalteu reagent were added and the solution was allowed to stand for $5 \mathrm{~min}$. Next, $1.0 \mathrm{~mL}$ of $20 \% \mathrm{Na}_{2} \mathrm{CO}_{3}$ solution was added to the mixture and the solution was left at room temperature for 1h. Absorbance at $735 \mathrm{~nm}$ was read on a spectrophotometer as was that of a blank containing methanol. The phenolic content was calculated as gallic acid equivalent (GAE) by comparison with a calibration curve of gallic acid standard solutions (10-100 $\mu \mathrm{g} / \mathrm{mL}$ ) and was expressed as $\mathrm{mg}$ gallic acid equivalent per gram of dry extract. Data were reported as mean \pm SD for three replicates.

2.7. Total Flavonoid Content of Extracts. Total flavonoid content was determined according to the aluminium chloride colorimetric assay with slight modification [68]. The samples were prepared at a concentration of $3.35 \mathrm{mg} / \mathrm{mL}$ in methanol. At time of $0 \mathrm{~min}, 250 \mu \mathrm{L}$ of standard solution or extract was mixed with $1 \mathrm{~mL}$ of Milli-Q water and $75 \mu \mathrm{L}$ of $5 \% \mathrm{NaNO}_{2}$. After $5 \mathrm{~min}, 75 \mu \mathrm{L}$ of $\mathrm{AlCl}_{3}(10 \%)$ was added to the solution and after $1 \mathrm{~min}, 500 \mu \mathrm{L}$ of $\mathrm{NaOH}(1 \mathrm{M})$ was added to the solution. Then the total solution was made up to $2.5 \mathrm{~mL}$ by adding Milli-Q water and mixed thoroughly. Absorbance of the mixture, pink in colour, was determined at $510 \mathrm{~nm}$ versus the prepared blank. The total flavonoid content was calculated as catechin equivalent by comparison to a calibration curve of catechin standard solutions $(10-100 \mu \mathrm{g} / \mathrm{mL})$ and was expressed as mg catechin equivalent per gram of dry weight. Samples were analysed in three replications.

2.8. Total Condensed Tannin Content of Extracts. Total condensed tannin content was determined by the method described by Michel et al. [69] with slight modification. The samples were prepared at a concentration of $1.25 \mathrm{mg} / \mathrm{mL}$ in methanol. Sample solution $(50 \mu \mathrm{L})$ was mixed with $3 \mathrm{~mL}$ of $4 \%$ vanillin in methanol followed by the addition of $1.5 \mathrm{~mL}$ of $11.6 \mathrm{M} \mathrm{HCl}$. The well mixed solution was allowed to stand for $15 \mathrm{~min}$ and absorbance was measured at $500 \mathrm{~nm}$ against a blank. The total condensed tannin content was calculated as catechin equivalent after comparison with a calibration curve of catechin standard solutions $(10-100 \mu \mathrm{g} / \mathrm{mL})$ and was expressed as mg catechin equivalent per gram of dry extracts. Samples were analysed in three replications.

\subsection{In Vitro Antioxidant Assays}

2.9.1. 2,2-Diphenyl-1-picrylhydrazyl (DPPH) Assay. The antioxidant activities of the plant extracts were determined using the DPPH radical scavenging protocol described by Liu et al. [70]. The solutions of extracts were prepared at different concentrations $(6.75-100 \mu \mathrm{g} / \mathrm{mL})$ in methanol. DPPH solution $(50 \mu \mathrm{L}$ and $1 \mathrm{mM})$ in methanol was mixed with $200 \mu \mathrm{L}$ of sample solution and the solution mixed well by shaking before being left standing at room temperature for $30 \mathrm{~min}$ in the dark. The absorbance was measured at $517 \mathrm{~nm}$ against the blank (methanol). Ascorbic acid at the same concentrations was used as the standard. All measurements were done in triplicate. The scavenging ability of the extracts was calculated using the following equation:

$$
\text { Inhibition }(\%)=\frac{\left[\left(\mathrm{Abs}_{\text {control }}-\mathrm{Abs}_{\text {sample }}\right)\right]}{\mathrm{Abs}_{\text {control }}} \times 100 \text {. }
$$

From a plot of concentration against percentage of inhibition, a linear regression analysis was performed to determine the 
$\mathrm{IC}_{50}$ value (the extract concentration that could scavenge 50\% of the DPPH radicals).

2.9.2. ABTS Radical Cation Scavenging Activity Assay. The ABTS assay method was used as directed by Adedapo et al. [71]. A stock solution was prepared by mixing $7 \mathrm{mM} \mathrm{ABTS}^{\circ+}$ solution in water and $2.4 \mathrm{mM}$ potassium persulfate solution in water in equal volumes and allowing the mixture to react for 12-16 $\mathrm{h}$ at room temperature in the dark so that it reached a stable oxidative state. The working solution was then prepared by diluting with methanol to an initial absorbance of $0.700 \pm 0.020\left(\mathrm{Abs}_{\text {control }}\right)$ at $734 \mathrm{~nm}$. The solution was prepared fresh for each analysis. The solutions of extracts were prepared at different concentrations $(6.75-100 \mu \mathrm{g} / \mathrm{mL})$ in methanol. Then $1 \mathrm{~mL}$ of sample solution was mixed with $1 \mathrm{~mL}$ of $\mathrm{ABTS}^{*+}$ solution and the absorbance was measured at $734 \mathrm{~nm}$ after $7 \mathrm{~min}$ against methanol as the blank. All measurements were done in triplicate. Trolox was used as a positive control. The percentage of scavenging inhibition capacity of $\mathrm{ABTS}^{\circ+}$ of the extract was calculated using the following formula:

$$
\text { Inhibition }(\%)=\frac{\left[\left(\mathrm{Abs}_{\text {control }}-\mathrm{Abs}_{\text {sample }}\right)\right]}{\left(\mathrm{Abs}_{\text {control }}\right)} \times 100 .
$$

$\mathrm{IC}_{50}$ values of the plant extracts were also determined for $\mathrm{ABTS}^{\bullet+}$.

\subsubsection{Ferric Reducing Antioxidant Power (FRAP) Assay.} The FRAP assay was carried out by following the method described by Wang et al. [72]. The FRAP reagent included $300 \mathrm{mM}$ acetate buffer $\left(3.1 \mathrm{~g}\right.$ of $\mathrm{CH}_{3} \mathrm{COONa}$ in $16 \mathrm{~mL}$ glacial acetic acid), $10 \mathrm{mM}$ TPTZ solution in $40 \mathrm{mM} \mathrm{HCl}$, and $20 \mathrm{mM} \mathrm{FeCl}_{3} \cdot 6 \mathrm{H}_{2} \mathrm{O}$ solution in the ratio of $10: 1: 1(\mathrm{v} / \mathrm{v})$. The solutions of extracts were prepared at a final concentration of $0.2 \mathrm{mg} / \mathrm{mL}$ in methanol. Sample solution $(400 \mu \mathrm{L})$ was mixed with $3 \mathrm{~mL}$ of freshly prepared FRAP solution and the solution incubated at $37^{\circ} \mathrm{C}$ in a water bath for $30 \mathrm{~min}$. The absorbance of the samples was then measured at $593 \mathrm{~nm}$. Trolox was used as a standard solution to draw the calibration curve in a concentration range of $10-100 \mu \mathrm{g} / \mathrm{mL}(Y=0.0056 x+0.0159$, $\left.R^{2}=0.9993\right)$. The FRAP results were calculated as $\mathrm{mg}$ of Trolox equivalent per gram extract. All experiments were done in triplicate.

\subsection{In Vitro Antibacterial Activity}

2.10.1. Microorganisms. The bacterial strains used included the Gram-positive bacterial strains, methicillin sensitive Staphylococcus aureus (MSSA, ATCC 29213), methicillin resistant Staphylococcus aureus (MRSA, ATCC BAA1026), and wild multidrug resistant Staphylococcus aureus (MDRSA, clinical isolate), and the Gram-negative bacterial strains, Pseudomonas aeruginosa (ATCC-27853) and Escherichia coli (ATCC 25922). All bacterial strains were kindly provided by Dr. John Merlino (Department of Microbiology, Concord Hospital, Sydney) and the work was approved by the Macquarie University Biosafety Committee (approval reference 08/06/LAB, KAA110412BHA).
2.10.2. Culture Media. Müller Hinton II (MH) broth (Bacto Laboratories Pty Ltd., Australia) was used for the growth of all the bacterial strains. All the culture media were prepared according to the manufacturer's instructions.

2.10.3. MTT Microdilution Assay. Minimum inhibitory concentrations (MIC) were determined using the MTT microdilution method as outlined by Appendino et al. with minor modification [73]. A solution of each sample $(10 \mathrm{mg} / \mathrm{mL})$ in $20 \%$ aqueous DMSO along with that of a suitable antibiotic $(1 \mathrm{mg} / \mathrm{mL}$, vancomycin for Gram-positive strains and gentamycin for Gram-negative strains) was prepared and serially diluted to give a final plant sample concentration of $2-1000 \mu \mathrm{g} / \mathrm{mL}$ and antibiotic concentration of 0.05 to $100 \mu \mathrm{g} / \mathrm{mL}$ in 96 -well clear bottom microtitre plates. Test samples $(20 \mu \mathrm{L})$ were inoculated with $175 \mu \mathrm{L}$ of microbial culture $\left(A_{600}=0.08\right.$ diluted 100 -fold in MH broth); a sterile broth control was included. A $20 \%$ DMSO control was also included and the plates were incubated at $37^{\circ} \mathrm{C}$. After $18 \mathrm{hrs}$ of incubation $5 \mu \mathrm{L}$ of a methanolic solution $(5 \mathrm{mg} / \mathrm{mL})$ of MTT (3-(4,5-dimethylthiazol-2-yl)-2,5-diphenyltetrazolium bromide) was added to each well and the plates further incubated at $37^{\circ} \mathrm{C}$ for $1 \mathrm{~h}$ to determine the MIC. MTT was used as an indicator of where microbial growth reduced the yellow tetrazolium bromide to a violet formazan. MIC was described as the lowest concentration of the test compounds that inhibited visible growth of the microorganisms (the last well showing no colour change of MTT from yellow to blue).

2.11. GC-MS Analysis of n-Hexane Extract of Syncarpia glomulifera. The $70 \%$ aqueous ethanol extract $(6.0 \mathrm{~g})$ of $S$. glomulifera leaves was partitioned with $n$-hexane $(50 \mathrm{~mL} \times$ $3)$, dichloromethane $(50 \mathrm{~mL} \times 3)$, ethyl acetate $(50 \mathrm{~mL} \times$ 3), $n$-butanol $(50 \mathrm{~mL} \times 3)$, and water $(50 \mathrm{~mL} \times 3)$ to give $950 \mathrm{mg}, 1.0 \mathrm{~g}, 540 \mathrm{mg}, 1.6 \mathrm{~g}$, and $750 \mathrm{mg}$ of each partition, respectively. The partitions were tested for their antibacterial activity against sensitive and resistant strains of $S$. aureus, $E$. coli, and P. aeruginosa. The $n$-hexane extract was selected for GC-MS analysis by gas liquid chromatography (GLC) and gas chromatography-mass spectrometry (GC-MS). GLC was carried out on a BP-20 column $(60 \mathrm{~m} \times 0.25 \mathrm{~mm} \times 0.25 \mu \mathrm{m})$. The temperature program was $50^{\circ} \mathrm{C}(5 \mathrm{~min})$ to $220^{\circ} \mathrm{C}(15 \mathrm{~min})$ at $3^{\circ} \mathrm{C} / \mathrm{min}$ with helium as the carrier gas. The temperature of the injector and that of detector were both set at $220^{\circ} \mathrm{C}$. The BP- 20 column $(30 \mathrm{~m} \times 0.35 \mathrm{~mm} \times 0.25 \mu \mathrm{m})$, programmed from $35^{\circ} \mathrm{C}$ to $220^{\circ} \mathrm{C}$ at $3^{\circ} \mathrm{C} / \mathrm{min}$, was used for GC-MS with helium as the carrier gas and an injector temperature of $220^{\circ} \mathrm{C}$ for the column. Mass spectra were recorded in electron impact (EI) mode at $70 \mathrm{eV}$, scanning from 41 to $450 \mathrm{~m} / z$. Compounds were identified by their identical GC retention times and retention indices relative to $n$-alkanes and by comparison of their mass spectra with either pure standards or published spectra in the NIST GC-MS library and those in the literature [56-61].

2.12. Statistical Analysis. All results are expressed as means \pm standard deviation. Statistical analyses were performed using Microsoft Excel. The $\mathrm{IC}_{50}$ values were calculated by regression 
TABLE 2: Qualitative phytochemical screening of plant extracts.

\begin{tabular}{|c|c|c|c|c|c|c|c|}
\hline Plant & Alkaloids & Flavonoids & Steroids & Terpenoids & Tannins & Saponins & Anthraquinones \\
\hline A. implexa & + & + & + & + & + & + & - \\
\hline A. falcata & - & + & + & + & + & - & + \\
\hline C. glabella & - & + & + & + & + & - & - \\
\hline E. haemastoma & + & + & + & + & + & + & + \\
\hline H. scandens & - & + & + & + & + & - & - \\
\hline S. glyciphylla & - & + & + & + & + & - & - \\
\hline S. quadrifida & - & + & + & + & + & - & - \\
\hline S. glomulifera & - & + & + & + & + & - & - \\
\hline
\end{tabular}

TABLE 3: Total phenol, flavonoid, and condensed tannin contents of plant extracts.

\begin{tabular}{lccc}
\hline Plant & $\begin{array}{c}\text { Total phenolic content } \\
(\mathrm{mg} \mathrm{GAE/g} \mathrm{plant} \mathrm{extract)}\end{array}$ & $\begin{array}{c}\text { Total flavonoid content } \\
(\mathrm{mg} \mathrm{CE} / \mathrm{g} \text { plant extract) }\end{array}$ & $\begin{array}{c}\text { Total condensed tannin content } \\
\text { (mg CE/g plant extract) }^{*}\end{array}$ \\
\hline A. falcata & $451.67 \pm 1.26$ & $183.33 \pm 6.04$ & $39.86 \pm 2.36$ \\
A. implexa & $486.71 \pm 9.90$ & $133.97 \pm 6.12$ & $72.63 \pm 5.03$ \\
C. glabella & $275.52 \pm 8.56$ & $168.57 \pm 0.35$ & $29.41 \pm 2.50$ \\
E. haemastoma & $656.22 \pm 5.07$ & $172.4 \pm 3.55$ & $105.97 \pm 5.29$ \\
H. scandens & $174.66 \pm 4.09$ & $77.47 \pm 3.96$ & $21.97 \pm 2.31$ \\
S. glyciphylla & $243.47 \pm 5.90$ & $91.25 \pm 4.85$ & $14.67 \pm 1.22$ \\
S. quadrifida & $52.46 \pm 0.63$ & $70.5 \pm 1.45$ & $9.41 \pm 2.04$ \\
S. glomulifera & $171.41 \pm 5.62$ & $58.03 \pm 2.15$ & $17.41 \pm 2.04$ \\
\hline
\end{tabular}

${ }^{*}$ Results are mean \pm SD from three sets of independent experiments, each set in triplicate.

analysis. Values with $p<0.05$ and $p<0.01$ were considered statistically significant and very significant, respectively. The experimental results were compared by paired $t$-test (two sided).

\section{Results and Discussion}

3.1. Phytochemical Screening. Qualitative phytochemical tests of the $70 \%$ aqueous ethanol extracts of the eight plants showed the presence of alkaloids, terpenoids, flavonoids, steroids, saponins, tannins, and anthraquinones (Table 2). These classes of phytochemicals are known to possess a variety of biological activities including antimicrobial, antioxidant, anti-inflammatory, antiplasmodial, and anticancer activities [74-84]. These findings may partially justify the traditional use of the examined plants in the treatment of wound and skin infections and free radical mediated diseases and indicate that they may serve as a source of bioactive compounds against these illnesses.

\subsection{Total Phenol, Flavonoid, and Condensed Tannin Contents.} Phenolic compounds are effective hydrogen donors, making them good antioxidants [80]. Plant derived polyphenolic flavonoids are also well known to exhibit antioxidant activity. Flavonoids reduce free radicals by quenching, upregulating, or protecting antioxidant defences and chelating radical intermediate compounds [85]. It is also reported that tannins are 15-30 times more effective in quenching peroxyradicals than simple phenolics [86].

The phenolics and polyphenols are one of the largest groups of secondary metabolites to have exhibited antimicrobial activity [87]. The site(s) and number of phenol groups are thought to be related to their relative toxicity to microorganisms, with evidence that increased hydroxylation results in increased toxicity [88]. Naturally occurring plant flavonoids have also been reported to possess antimicrobial activities [79, 89, 90]. The variation in the antibacterial activity of flavonoids is known to be related to their chemical structure, especially in regard to the number and positions of methoxy and phenolic groups within their structures [9193]. The antimicrobial effects of tannins have also been widely recognised [94-96]. Therefore, the total phenolic, flavonoid, and condensed tannin contents of the eight plant extracts were examined to see if their traditional uses for the treatment of skin related ailments could be linked to the presence of these classes of compounds.

The results showed that the amount of total phenolic, flavonoid, and condensed tannin contents differed significantly $(p<0.05)$ among the extracts of the tested medicinal plants (Table 3, Figure 1). The total phenolic contents were determined as mg GAE/g extract on comparison with a standard gallic acid graph. Three extracts showed very high phenolic contents (>400 mg GAE/g): E. haemastoma, A. implexa, and A. falcata with values of $656.2 \pm 5.1$, $486.7 \pm 9.9$, and $451.7 \pm 1.3 \mathrm{mg} \mathrm{GAE} / \mathrm{g}$ of extract, respectively. 
TABLE 4: Antioxidant activities of plant extracts.

\begin{tabular}{lccc}
\hline Plant & DPPH IC $_{50}(\mu \mathrm{g} / \mathrm{mL})$ & ABTS IC $_{50}(\mu \mathrm{g} / \mathrm{mL})$ & FRAP $(\mu \mathrm{mol} \mathrm{Trolox} / \mathrm{g})$ \\
\hline A. falcata & $217.03 \pm 3.80$ & $111.47 \pm 0.88$ & $1991.46 \pm 2.73$ \\
A. implexa & $130.20 \pm 5.37$ & $107.05 \pm 1.38$ & $2913.87 \pm 6.76$ \\
C. glabella & $255.23 \pm 2.32$ & $203.46 \pm 1.25$ & $1796.22 \pm 4.58$ \\
E. haemastoma & $51.99 \pm 1.17$ & $61.72 \pm 0.53$ & $6189.64 \pm 9.45$ \\
H. scandens & $348.69 \pm 2.90$ & $321.03 \pm 3.46$ & $1635.51 \pm 5.94$ \\
S. glyciphylla & $439.33 \pm 2.05$ & $351.46 \pm 1.98$ & $185.80 \pm 5.85$ \\
S. quadrifida & $2190.13 \pm 2.16$ & $1824.96 \pm 4.26$ & $722.41 \pm 6.25$ \\
S. glomulifera & $235.86 \pm 3.50$ & $287.98 \pm 1.75$ & $1522.11 \pm 4.92$ \\
\hline Ascorbic acid & $71.58 \pm 0.99$ & & $231.90 \pm 1.76$ \\
Trolox & & & \\
\hline
\end{tabular}

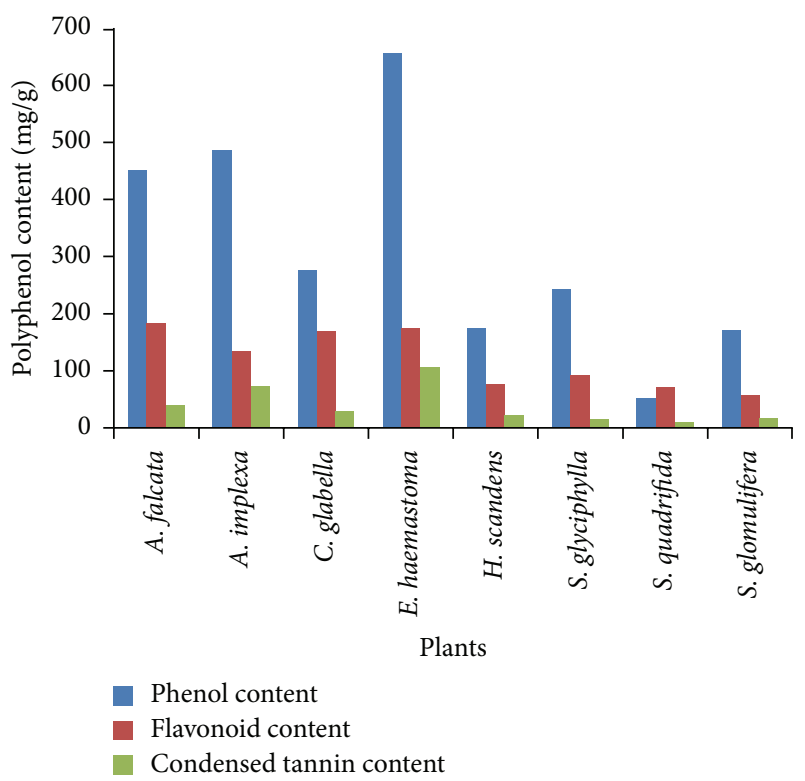

FIGURE 1: Polyphenolic contents (mg/g) of plant extracts.

C. glabella and S. glyciphylla showed reasonable phenolic contents (>200.0 mg GAE/g) of $275.5 \pm 8.6$ and $243.5 \pm$ $5.9 \mathrm{mg} \mathrm{GAE} / \mathrm{g}$ of extract. S. quadrifida showed the lowest phenolic content at $52.5 \pm 0.6 \mathrm{mg} \mathrm{GAE} / \mathrm{g}$ extract. The total flavonoid content was determined as $\mathrm{mg} \mathrm{CE} / \mathrm{g}$ extract after comparison with a catechin standard graph. The highest total flavonoid content was identified for A. falcata at $183.3 \pm$ $6.0 \mathrm{mgCE} / \mathrm{g}$ of extract and the lowest for S. glomulifera at $58.0 \pm 2.2 \mathrm{mg} \mathrm{CE} / \mathrm{g}$ of extract. The total condensed tannin content was evaluated as $\mathrm{mg} \mathrm{CE} / \mathrm{g}$ of extract after comparison with a catechin standard graph. E. haemastoma showed the highest condensed tannin content at $106.0 \pm 5.3 \mathrm{mg} \mathrm{CE} / \mathrm{g}$ of extract and S. quadrifida the lowest at $9.4 \pm 2.0 \mathrm{mg} \mathrm{CE} / \mathrm{g}$ of extract.

The results revealed that the level of phenolic compounds and condensed tannins was the highest in the $70 \%$ ethanolic extracts from the sap of E. haemastoma and bark of A. falcata and $A$. implexa. These results were significantly higher than that of the leaves of the other plants investigated.

\subsection{In Vitro Antioxidant Activity}

3.3.1. DPPH Radical Scavenging Activity. The results of the free radical scavenging activity of the extracts are shown in Table 4. The dose-response curves of the DPPH radical scavenging activities of the eight plant extracts were compared with that of ascorbic acid (Figure 2). In the DPPH assay, all extracts examined except for that of $S$. quadrifida showed radical scavenging activity in a concentration dependent manner and were significantly different $(p<0.01)$. This result agreed with an earlier report by Motalleb et al. [97] that showed that the scavenging effects on the DPPH radical increase sharply with increasing concentration of the samples and standards. The highest antioxidant activity was obtained for the extract of E. haemastoma $\left(\mathrm{IC}_{50} 52.0 \pm 1.2 \mu \mathrm{g} / \mathrm{mL}\right.$ and standard ascorbic acid $\mathrm{IC}_{50} 71.6 \pm 1.0 \mu \mathrm{g} / \mathrm{mL}$ ).

3.3.2. ABTS $^{+}$Scavenging Activity. The antioxidant activities of the plant extracts towards $\mathrm{ABTS}^{\circ+}$ were also determined (Table 4, Figure 2). All extracts showed the ability to neutralise the radical cation $\mathrm{ABTS}^{\circ+}$, with significant differences at $p<0.01$. The highest activity was obtained for the $E$. haemastoma extract with $\mathrm{IC}_{50}$ value of $61.7 \pm 0.5 \mu \mathrm{g} / \mathrm{mL}$, followed by $A$. implexa and $A$. falcata with $\mathrm{IC}_{50}$ values of $107.1 \pm 1.4 \mu \mathrm{g} / \mathrm{mL}$ and $111.5 \pm 0.9 \mu \mathrm{g} / \mathrm{mL}$, respectively. These extracts could be seen to be rapid and effective scavengers of the $\mathrm{ABTS}^{\circ+}$ radical (Figure 2) and their activities were comparable with that of Trolox.

3.3.3. Ferric Reducing Antioxidant Power (FRAP) Assay. The FRAP assay was used to evaluate the antioxidant properties of the extracts based on their ability to reduce ferric (III) to ferrous (II). The results obtained from the extracts (Table 4) were significantly different $(p<0.01)$. For this assay it was also found that the extract of E. haemastoma provided the highest antioxidant activity with a FRAP value of $6189 \pm$ $9.5 \mu \mathrm{mol}$ Trolox equivalent/g, followed by $A$. implexa and $A$. falcata with FRAP values of $2913 \pm 6.8$ and $1991 \pm 2.7 \mu \mathrm{mol}$ Trolox equivalent/g, respectively.

Based on the results of all three assays, it can be seen that the sap extract of E. haemastoma and bark extracts of A. implexa and A. falcata possess the strongest free radical scavenging activities and reducing capacities of all the plant 

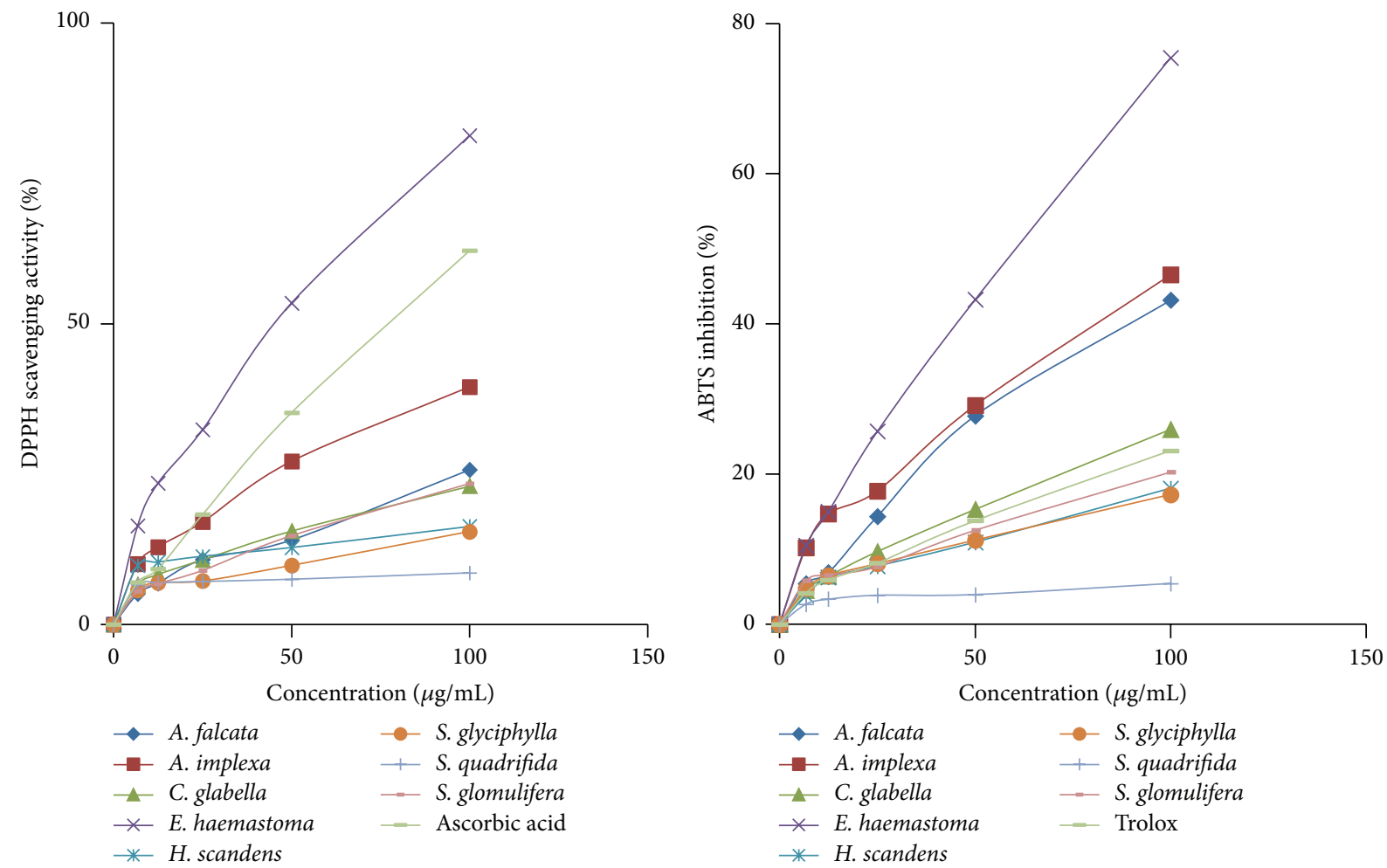

FIGURE 2: DPPH and ABTS scavenging activities of plant extracts.

extracts analysed, indicating that they may be useful for treating free radical-related diseases. The scavenging of the $\mathrm{ABTS}^{\circ+}$ radical by the extracts was found to be higher than that for the DPPH radical. It is well known that the antioxidant activity of a plant extract largely depends on both its composition and the test system [72].

\subsection{Correlation between the Total Phenolic and Flavonoid} Contents and Antioxidant Activities. Table 5 shows the correlations (linear regression coefficients, $R^{2}$ ) between the total phenolic contents (TPC) and total flavonoid contents (TFC) and the antioxidant assay results for the plant extracts. All the antioxidant assay results showed very good correlation $\left(R^{2}>0.9\right)$ with the TPC and TFC values except for that of $S$. quadrifida, which showed poor correlation between ABTS and TFC $\left(R^{2}=0.7953\right)$. The significant correlations between the antioxidant properties and TPCs and TFCs of the extracts may indicate that the phenolic and flavonoid type compounds contained within the plant extracts are the major contributors to their antioxidant properties.

3.5. Antibacterial Activities. The $70 \%$ aqueous ethanol extracts of the plants were tested for their antibacterial activity using the MTT microdilution assay method against three Gram-positive (S. aureus (MSSA) ATCC 29213, S. aureus (MRSA) ATCC BAA 1026, S. aureus (MDRSA)) and two Gram-negative (E. coli $\beta$-lactamase negative ATCC 25922 and $P$. aeruginosa ATCC 27853) bacterial strains. The minimum inhibitory concentration (MIC) values for the extracts are shown in Table 6. None of the extracts showed activity against the Gram-negative bacterial strains, even at a concentration of $1 \mathrm{mg} / \mathrm{mL}$. Seven of the eight extracts showed activity against the sensitive and/or resistant strains of $S$. aureus at MIC values of $\leq 1 \mathrm{mg} / \mathrm{mL}$, except for $S$. quadrifida which did not show any activity even at a concentration of $1 \mathrm{mg} / \mathrm{mL}$.

According to Ríos and Recio [98] extracts possessing an MIC value equalling or less than $1000 \mu \mathrm{g} / \mathrm{mL}$ are considered to be active and worthy of further investigation. The $S$. glomulifera extract showed the greatest activity against sensitive and resistant strains of $S$. aureus with MIC values of $7.81 \mu \mathrm{g} / \mathrm{mL}$ against all three strains, followed by E. haemastoma and A. implexa with MIC values of $62.5 \mu \mathrm{g} / \mathrm{mL}$ and $125 \mu \mathrm{g} / \mathrm{mL}$, respectively, against the sensitive strain of $S$. aureus.

It is well known that phenolic compounds present in plant extracts play an important role in their antimicrobial effects [99]. Phytochemical screening of the extracts in this study showed that E. haemastoma, A. implexa, and A. falcata possess a high content of phenolic compounds. It has also been reported that the active constituents in $A$. implexa and $A$. falcata include tannins [99]. Therefore, it can be inferred that the antibacterial activities of these three plants may be due, at least in part, to their high phenolic and tannin contents. This is the first report of the antibacterial activities of all of these eight medicinal plants against sensitive and resistant strains of $S$. aureus. The promising antibacterial activities of the extracts provides preliminary support for the traditional uses of these plants for the treatment of skin and wound infections. 
TABLE 5: Correlation values $\left(R^{2}\right)$ between the antioxdant activities and total phenolic and total flavonoid contents of the plants extracts.

\begin{tabular}{|c|c|c|c|}
\hline Plant & $R^{2}(\mathrm{DPPH})$ & $R^{2}$ (ABTS) & $R^{2}$ (FRAP) \\
\hline \multicolumn{4}{|c|}{ A. falcata } \\
\hline TPC & 0.9984 & 0.9456 & 0.9844 \\
\hline TFC & 0.9881 & 0.9728 & 0.9969 \\
\hline \multicolumn{4}{|c|}{ A. implexa } \\
\hline TPC & 0.9768 & 0.9749 & 0.9832 \\
\hline TFC & 0.9157 & 0.9190 & 0.9025 \\
\hline \multicolumn{4}{|c|}{ C. glabella } \\
\hline TPC & 0.9695 & 0.9492 & 0.9675 \\
\hline TFC & 0.9431 & 0.9167 & 0.9405 \\
\hline \multicolumn{4}{|c|}{ E. haemastoma } \\
\hline TPC & 0.9989 & 0.9969 & 0.9981 \\
\hline TFC & 0.9737 & 0.9946 & 0.9926 \\
\hline \multicolumn{4}{|c|}{ H. scandens } \\
\hline TPC & 0.9987 & 0.9999 & 0.9675 \\
\hline TFC & 0.9915 & 0.9857 & 0.9806 \\
\hline \multicolumn{4}{|c|}{ S. glyciphylla } \\
\hline TPC & 0.9991 & 0.9967 & 0.9977 \\
\hline TFC & 0.9888 & 0.9938 & 0.9922 \\
\hline \multicolumn{4}{|c|}{ S. glomulifera } \\
\hline ТPC & 0.9962 & 0.9939 & 0.9963 \\
\hline TFC & 0.9993 & 0.9981 & 0.9993 \\
\hline \multicolumn{4}{|c|}{ S. quadrifida } \\
\hline TPC & 0.9961 & 0.9357 & 0.9988 \\
\hline TFC & 0.9261 & 0.7953 & 0.9683 \\
\hline
\end{tabular}

TPC: total phenolic content; TFC: total flavonoid content.

TABle 6: Antibacterial activities of plant extracts.

\begin{tabular}{|c|c|c|c|}
\hline \multirow[b]{2}{*}{ Plant } & \multicolumn{3}{|c|}{$\operatorname{MIC}(\mu \mathrm{g} / \mathrm{mL})$} \\
\hline & $\begin{array}{c}\text { S. aureus } \\
\text { (MSSA) }\end{array}$ & $\begin{array}{l}\text { S. aureus } \\
\text { (MRSA) }\end{array}$ & $\begin{array}{l}\text { S. aureus } \\
\text { (MDRSA) }\end{array}$ \\
\hline A. falcata & 250 & 1000 & 1000 \\
\hline A. implexa & 125 & 250 & 250 \\
\hline C. glabella & 500 & 1000 & 1000 \\
\hline E. haemastoma & 62.5 & 125 & 125 \\
\hline H. scandens & 500 & 1000 & 1000 \\
\hline S. glyciphylla & 1000 & na & na \\
\hline S. quadrifida & na & na & na \\
\hline S. glomulifera & 7.81 & 7.81 & 7.81 \\
\hline Vancomycin & 0.002 & 0.002 & 0.002 \\
\hline
\end{tabular}

na: not active at concentration of $1 \mathrm{mg} / \mathrm{mL}$. MIC: minimum inhibitory concentration.

The extract of $S$. glomulifera leaves showed the highest antibacterial activity with MIC values of $7.81 \mu \mathrm{g} / \mathrm{mL}$ against the methicillin sensitive, methicillin resistant, and multidrug resistant strains of $S$. aureus. Therefore, this extract was chosen for further investigation. The crude $70 \%$ aqueous ethanol extract was partitioned with $n$-hexane, dichloromethane, ethyl acetate, $n$-butanol, and water and the partitions tested
TABLE 7: Antibacterial activities of Syncarpia glomulifera partitions.

\begin{tabular}{lcccc}
\hline \multirow{2}{*}{ Extracts } & \multicolumn{4}{c}{ MIC $(\mu \mathrm{g} / \mathrm{mL})$} \\
& $\begin{array}{c}\text { S. aureus } \\
(\mathrm{MSSA})\end{array}$ & $\begin{array}{c}\text { S. aureus } \\
(\mathrm{MRSA})\end{array}$ & $\begin{array}{c}\text { S. aureus } \\
(\mathrm{MDRSA})\end{array}$ & E. coli \\
\hline$n$-Hexane & 7.81 & 7.81 & 7.81 & 1000 \\
Dichloromethane & 31.25 & 31.25 & 125 & na \\
Ethyl acetate & $\mathrm{na}$ & $\mathrm{na}$ & $\mathrm{na}$ & na \\
$n$-Butanol & 1000 & 1000 & 1000 & na \\
Water & 1000 & $\mathrm{na}$ & $\mathrm{na}$ & na \\
\hline Vancomycin & 0.002 & 0.002 & 0.002 & $\mathrm{NT}$ \\
Gentamycin & $\mathrm{NT}$ & $\mathrm{NT}$ & $\mathrm{NT}$ & 1.69 \\
\hline
\end{tabular}

na: not active at concentration of $1000 \mu \mathrm{g} / \mathrm{mL}$. NT: not tested. MIC: minimum inhibitory concentration.

for their antibacterial activity against sensitive and resistant strains of S. aureus, E. coli, and P. aeruginosa (Table 7). Among the five partitions, the $n$-hexane extract showed the greatest antibacterial activities against sensitive and resistant strains of $S$. aureus with MIC values of $7.81 \mu \mathrm{g} / \mathrm{mL}$ against all three strains. None of the extracts showed antibacterial activity against $P$. aeruginosa, and only the $n$-hexane partition showed activity against $E$. coli at a concentration of $1 \mathrm{mg} / \mathrm{mL}$. As the $n$ hexane extract showed the greatest activity, it was chosen for GC-MS analysis to further explore its chemical constituents.

3.6. GC-MS Analysis of n-Hexane Extract of S. glomulifera. GC-MS analysis of the $n$-hexane extract of $S$. glomulifera showed that it predominantly contained monoterpene hydrocarbons ( $\alpha$-phellandrene, $p$-cymene, terpinolene), oxygenated monoterpenes (terpinen-4-ol, $\alpha$-terpineol), sesquiterpene hydrocarbons ( $\alpha$-copaene, $\beta$-elemene, aromadendrene, alloaromadendrene, $\alpha$-selinene, $\beta$-selinene, bicyclogermacrene, and viridiflorene), and oxygenated sesquiterpenes (spathulenol, cubenol, epicubenol, cubeban-11-ol, palustrol, epiglobulol, globulol, ledol, and viridiflorol) (Table 8). These phytoconstituents are in accordance with a previous report on the chemical composition of the leaf essential oil of $S$. glomulifera, but they are present in different concentrations [19]. This could be due to seasonal variation, the different collection sites, variances in the extraction processes, or other factors [100].

$\alpha$-Phellandrene, $\alpha$-copaene, aromadendrene, terpinen4-ol, $\alpha$-terpineol, palustrol, epiglobulol, cubenol, globulol, and spathulenol have been reported to have antibacterial activity against Gram-positive bacteria [20, 28, 31$33,42,43,47,52]$ and the presence of these bioactive phytoconstituents could be contributing to the strong antibacterial activity of the $n$-hexane extract. Bicyclogermacrene is reported to be a major component of the antibacterial essential oil from Zanthoxylum rhoifolium [39]. In addition, $\alpha$-phellandrene, $p$-cymene, terpinolene, $\alpha$-copaene, aromadendrene, terpinen-4-ol, alloaromadendrene, $\alpha$-terpineol, palustrol, ledol, epicubenol, globulol, viridiflorol, and spathulenol are known to possess other biological activities relevant to skin related ailments including antifungal, antioxidant, 
TABLE 8: GC-MS analysis of $n$-hexane extract of S. glomulifera on BP-20 column, phytoconstituents identified and their known biological activities.

\begin{tabular}{|c|c|c|c|}
\hline Compounds $^{1}$ & LRI values & $\begin{array}{l}\% \text { of identified } \\
\text { compounds }\end{array}$ & Known biological activities \\
\hline$\alpha$-Phellandrene & 1166 & 0.93 & Antibacterial [20], antifungal [20], antioxidant [21], larvicidal [22] \\
\hline p-Cymene & 1269 & 0.22 & Antifungal [23-26], antioxidant [21] \\
\hline Terpinolene & 1282 & 0.08 & Antioxidant [21], antiviral [27], larvicidal [22] \\
\hline$\alpha$-Copaene & 1499 & 0.10 & Antibacterial [28], antidermatophytic [29] \\
\hline$\beta$-Elemene & 1600 & 0.10 & Anticancer $[30]$ \\
\hline Aromadendrene & 1603 & 2.33 & Antibacterial [31], antioxidant [21] \\
\hline Terpinen-4-ol & 1613 & 0.18 & $\begin{array}{l}\text { Antibacterial }[32,33] \text {, antifungal }[33,34] \text {, antioxidant }[21] \text {, } \\
\text { antiseptic [35], antiviral }[27,36]\end{array}$ \\
\hline Alloaromadendrene & 1643 & 0.64 & Antineoplastic [37], antioxidant [38] \\
\hline Viridiflorene & 1681 & 0.13 & None found \\
\hline Geranial & 1685 & 0.92 & None found \\
\hline$\alpha$-Terpineol & 1696 & 0.41 & Antibacterial [33], antifungal $[33,34]$, antiviral $[27,36]$ \\
\hline$\beta$-Selinene & 1715 & 0.23 & None found \\
\hline$\alpha$-Selinene & 1722 & 0.26 & None found \\
\hline Bicyclogermacrene & 1733 & 0.60 & Antibacterial $[39]^{*}$, antitumor $[40]^{*}$, cytotoxic $[41]$ \\
\hline Palustrol & 1931 & 0.26 & Antibacterial [42], antifungal [42], antitumor [42] \\
\hline Cubeban-11-ol (cis) & 2012 & 0.27 & None found \\
\hline Epiglobulol & 2018 & 1.08 & Antibacterial [43], uterus relaxant [44] \\
\hline Ledol & 2034 & 0.95 & Antimicrobial [45], anti-inflammatory [45], antineoplastic [37] \\
\hline Cubenol & 2058 & 0.70 & Antibacterial [28] \\
\hline Cubeban-11-ol (trans) & 2064 & 0.83 & None found \\
\hline Epicubenol & 2070 & 0.36 & Antifungal $[46]$ \\
\hline Globulol & 2080 & 5.31 & $\begin{array}{l}\text { Antibacterial [43, 47], antifungal [47], antioxidant [48], sedative } \\
\text { and anaesthetic [49] }\end{array}$ \\
\hline Viridiflorol & 2088 & 1.88 & Acetylcholinesterase inhibitory [50], antifungal [51] \\
\hline Spathulenol & 2129 & 0.96 & $\begin{array}{l}\text { Antibacterial [52], anticancer [53], anti-inflammatory [54 }]^{*} \text {, } \\
\text { immunomodulatory [55], uterus relaxant [44] }\end{array}$ \\
\hline
\end{tabular}

${ }^{1}$ The compounds were identified by their GC retention times and linear retention indices relative to $n$-alkanes and by comparison of their mass spectra with pure standards or published literature data [56-61]. ${ }^{*}$ Major components of essential oils with biological activities.

anti-inflammatory, and antiseptic activities $[20,21,23-26,29$, $33-35,38,42,45-48,51,54]$.

\section{Conclusion}

Our study has shown that extracts of E. haemastoma, A. implexa, A. falcata, and S. glomulifera contain antioxidant and antibacterial compounds. The highest in vitro antioxidant activity of the plant extracts was found for E. haemastoma, with results comparable with that of the standard compound, ascorbic acid. S. glomulifera and E. haemastoma presented the best antibacterial activities against methicillin sensitive, methicillin resistant, and multidrug resistant strains of $S$. aureus, with MIC values between 7.81 and $125 \mu \mathrm{g} / \mathrm{mL}$. GCMS analysis of the $n$-hexane extract of $S$. glomulifera revealed the presence of antioxidant and antibacterial compounds. Thus, the results of this study support the use of these plants as traditional medicines for the treatment of skin related ailments including sores, wounds, and skin infections by New South Wales Aboriginal people.

\section{Competing Interests}

The authors declare that they have no conflict of interests.

\section{Acknowledgments}

The authors thank the Yaegl Community Elders, in particular, Ronald Heron, Jessie Randall, Della Walker, Lillian Williams, Judith Breckenridge, Carmel Charlton, Darren King, Rosemarie Vesper, Muriel Burns, Beatrice Heron, Owen Kapeen, Thelma Kapeen, Eileen McLeay, Glenda McPhail, Lester Mercy, Lenore Parker, Irene Randall, Kevin Randall, and Lenny Waters, for sharing their knowledge on behalf of the Yaegl Community. The authors wish to thank Associate Professor Paul Prenzler and Mr. Daniel Bucio Noble for 
providing training on the antioxidant assays. The authors would also like to acknowledge Dr. John Merlino for providing the microbial strains. This project would have not been possible without the financial support provided by Macquarie University in the form of a Ph.D. scholarship for Kaisarun Akter and funding from the National Health and Medical Research Council (NH\&MRC, \#488504, and \#1028092).

\section{References}

[1] M. Pennacchio, A. S. Kemp, R. P. Taylor, K. M. Wickens, and L. Kienow, "Interesting biological activities from plants traditionally used by Native Australians," Journal of Ethnopharmacology, vol. 96, no. 3, pp. 597-601, 2005.

[2] E. A. Palombo and S. J. Semple, "Antibacterial activity of traditional Australian medicinal plants," Journal of Ethnopharmacology, vol. 77, no. 2-3, pp. 151-157, 2001.

[3] J. Packer, J. Gaikwad, D. Harrington, S. Ranganathan, J. Jamie, and S. Vemulpad, "Medicinal plants of New South Wales, Australia," in Genetic Resources, Chromosome, Engineering and Crop Improvement, pp. 259-296, CRC Press, Boca Raton, Fla, USA, 2012.

[4] E. McMeniman, L. Holden, T. Kearns et al., "Skin disease in the first two years of life in Aboriginal children in East Arnhem Land," Australasian Journal of Dermatology, vol. 52, no. 4, pp. 270-273, 2011.

[5] E. R. Zielins, E. A. Brett, A. Luan et al., "Emerging drugs for the treatment of wound healing," Expert Opinion on Emerging Drugs, vol. 20, no. 2, pp. 235-246, 2016.

[6] L. M. Jarvis, "Imminent threat," Chemical and Engineering News, vol. 86, no. 15, pp. 21-24, 2008.

[7] L. A. Mitscher, "Coevolution: mankind and microbes," Journal of Natural Products, vol. 71, no. 3, pp. 497-509, 2008.

[8] R. Edwards and K. G. Harding, "Bacteria and wound healing," Current Opinion in Infectious Diseases, vol. 17, no. 2, pp. 91-96, 2004.

[9] C. K. Sen, S. Khanna, G. Gordillo, D. Bagchi, M. Bagchi, and S. Roy, "Oxygen, oxidants, and antioxidants in wound healing: an emerging paradigm," Annals of the New York Academy of Sciences, vol. 957, no. 1, pp. 239-249, 2002.

[10] J. Packer, N. Brouwer, D. Harrington et al., "An ethnobotanical study of medicinal plants used by the Yaegl Aboriginal community in northern New South Wales, Australia," Journal of Ethnopharmacology, vol. 139, no. 1, pp. 244-255, 2012.

[11] J. Packer, T. Naz, D. Harrington, J. F. Jamie, and S. R. Vemulpad, "Antimicrobial activity of customary medicinal plants of the Yaegl Aboriginal community of northern New South Wales, Australia: a preliminary study," BMC Research Notes, vol. 8, no. 1, pp. 276-282, 2015.

[12] T. Naz, J. Packer, P. Yin et al., "Bioactivity and chemical characterisation of Lophostemon suaveolens - an endemic Australian Aboriginal traditional medicinal plant," Natural Product Research, vol. 30, no. 6, pp. 693-696, 2016.

[13] E. V. Lassak and T. McCarthy, Australian Medicinal Plants, New Holland, Sydney, Australia, 2008.

[14] Y. Murai, G. Kokubugata, M. Yokota, J. Kitajima, and T. Iwashina, "Flavonoids and anthocyanins from six Cassytha taxa (Lauraceae) as taxonomic markers," Biochemical Systematics and Ecology, vol. 36, no. 9, pp. 745-748, 2008.

[15] A.-C. Huang, A. Wilde, J. Ebmeyer, G. K. Skouroumounis, and D. K. Taylor, "Examination of the phenolic profile and antioxidant activity of the leaves of the australian native plant Smilax glyciphylla," Journal of Natural Products, vol. 76, no. 10, pp. 1930-1936, 2013.

[16] T. Smyth, V. N. Ramachandran, P. Brooks, and W. F. Smyth, "A study of the antibacterial activities of selected Australian medicinal plants," Journal of Pharmacognosy and Phytotherapy, vol. 1, no. 6, pp. 82-86, 2009.

[17] W. N. Setzer, M. C. Setzer, R. B. Bates, and B. R. Jackes, "Biologically active triterpenoids of Syncarpia glomulifera bark extract from Paluma, North Queensland, Australia," Planta Medica, vol. 66, no. 2, pp. 176-177, 2000.

[18] J. L. Courtney, E. V. Lassak, and G. B. Speirs, "Leaf wax constituents of some Myrtaceous species," Phytochemistry, vol. 22, no. 4, pp. 947-949, 1983.

[19] J. J. Brophy, R. S. Goldsack, A. R. Bean, P. I. Forster, and C. J. R. Fookes, "The leaf essential oils of the genus Syncarpia Ten. (Myrtaceae)," Flavour and Fragrance Journal, vol. 11, no. 6, pp. 361-366, 1996.

[20] G. İşcan, N. Kirimer, F. Demirci, B. Demirci, Y. Noma, and K. H. C. Başer, "Biotransformation of (-)-(R)- $\alpha$-phellandrene: antimicrobial activity of its major metabolite," Chemistry and Biodiversity, vol. 9, no. 8, pp. 1525-1532, 2012.

[21] H. J. D. Dorman, P. Surai, and S. G. Deans, "In vitro antioxidant activity of a number of plant essential oils and phytoconstituents," Journal of Essential Oil Research, vol. 12, no. 2, pp. 241-248, 2000.

[22] S.-S. Cheng, C.-G. Huang, Y.-J. Chen, J.-J. Yu, W.-J. Chen, and S.-T. Chang, "Chemical compositions and larvicidal activities of leaf essential oils from two Eucalyptus species," Bioresource Technology, vol. 100, no. 1, pp. 452-456, 2009.

[23] C. Bouchra, M. Achouri, L. M. I. Hassani, and M. Hmamouchi, "Chemical composition and antifungal activity of essential oils of seven Moroccan Labiatae against Botrytis cinerea Pers: Fr," Journal of Ethnopharmacology, vol. 89, no. 1, pp. 165-169, 2003.

[24] E. Pinto, C. Pina-Vaz, L. Salgueiro et al., "Antifungal activity of the essential oil of Thymus pulegioides on Candida, Aspergillus and dermatophyte species," Journal of Medical Microbiology, vol. 55, no. 10, pp. 1367-1373, 2006.

[25] C. Pina-Vaz, A. G. Rodrigues, E. Pinto et al., "Antifungal activity of Thymus oils and their major compounds," Journal of the European Academy of Dermatology and Venereology, vol. 18, no. 1, pp. 73-78, 2004.

[26] S. Kordali, A. Cakir, H. Ozer, R. Cakmakci, M. Kesdek, and E. Mete, "Antifungal, phytotoxic and insecticidal properties of essential oil isolated from Turkish Origanum acutidens and its three components, carvacrol, thymol and p-cymene," Bioresource Technology, vol. 99, no. 18, pp. 8788-8795, 2008.

[27] A. Garozzo, R. Timpanaro, B. Bisignano, P. M. Furneri, G. Bisignano, and A. Castro, "In vitro antiviral activity of Melaleuca alternifolia essential oil," Letters in Applied Microbiology, vol. 49, no. 6, pp. 806-808, 2009.

[28] C. Solís, J. Becerra, C. Flores, J. Robledo, and M. Silva, “Antibacterial and antifungal terpenes from Pilgerodendron uviferum (D. Don) Florin," Journal of the Chilean Chemical Society, vol. 49, no. 2, pp. 157-161, 2004.

[29] E. Houël, A. M. S. Rodrigues, A. Jahn-Oyac et al., "In vitro antidermatophytic activity of Otacanthus azureus (Linden) Ronse essential oil alone and in combination with azoles," Journal of Applied Microbiology, vol. 116, no. 2, pp. 288-294, 2014.

[30] G. Wang, X. Li, F. Huang et al., "Antitumor effect of $\beta$-elemene in non-small-cell lung cancer cells is mediated via induction of 
cell cycle arrest and apoptotic cell death," Cellular and Molecular Life Sciences, vol. 62, no. 7-8, pp. 881-893, 2005.

[31] S. Mulyaningsih, F. Sporer, J. Reichling, and M. Wink, "Antibacterial activity of essential oils from Eucalyptus and of selected components against multidrug-resistant bacterial pathogens," Pharmaceutical Biology, vol. 49, no. 9, pp. 893-899, 2011.

[32] S. Inouye, T. Takizawa, and H. Yamaguchi, "Antibacterial activity of essential oils and their major constituents against respiratory tract pathogens by gaseous contact," Journal of Antimicrobial Chemotherapy, vol. 47, no. 5, pp. 565-573, 2001.

[33] C. F. Carson and T. V. Riley, "Antimicrobial activity of the major components of the essential oil of Melaleuca alternifolia," Journal of Applied Bacteriology, vol. 78, no. 3, pp. 264-269, 1995.

[34] K. A. Hammer, C. F. Carson, and T. V. Riley, "Antifungal activity of the components of Melaleuca alternifolia (tea tree) oil," Journal of Applied Microbiology, vol. 95, no. 4, pp. 853-860, 2003.

[35] S. S. Budhiraja, M. E. Cullum, S. S. Sioutis, L. Evangelista, and S. T. Habanova, "Biological activity of Melaleuca alternifolia (tea tree) oil component, terpinen-4-ol, in human myelocytic cell line HL-60," Journal of Manipulative and Physiological Therapeutics, vol. 22, no. 7, pp. 447-453, 1999.

[36] A. Astani, J. Reichling, and P. Schnitzler, "Comparative study on the antiviral activity of selected monoterpenes derived from essential oils," Phytotherapy Research, vol. 24, no. 5, pp. 673-679, 2010.

[37] M. F. C. Matos, L. I. S. P. Leite, D. Brustolim et al., "Antineoplastic activity of selected constituents of Duguetia glabriuscula," Fitoterapia, vol. 77, no. 3, pp. 227-229, 2006.

[38] C.-W. Yu, W.-H. Li, F.-L. Hsu, P.-L. Yen, S.-T. Chang, and V. H.-C. Liao, "Essential oil alloaromadendrene from mixedtype cinnamomum osmophloeum leaves prolongs the lifespan in caenorhabditis elegans," Journal of Agricultural and Food Chemistry, vol. 62, no. 26, pp. 6159-6165, 2014.

[39] W. de Abreu Gonzaga, A. D. Weber, S. R. Giacomelli et al., "Composition and antibacterial activity of the essential oils from Zanthoxylum rhoifolium," Planta Medica, vol. 69, no. 8, pp. 773-775, 2003.

[40] E. V. Costa, L. M. Dutra, M. J. Salvador, L. H. G. Ribeiro, F. R. Gadelha, and J. E. De Carvalho, "Chemical composition of the essential oils of Annona pickelii and Annona salzmannii (Annonaceae), and their antitumour and trypanocidal activities," Natural Product Research, vol. 27, no. 11, pp. 997-1001, 2013.

[41] S. D. S. Grecco, E. G. A. Martins, N. Girola et al., "Chemical composition and in vitro cytotoxic effects of the essential oil from Nectandra leucantha leaves," Pharmaceutical Biology, vol. 53, no. 1, pp. 133-137, 2015.

[42] K. O. Al-Footy, W. M. Alarif, F. Asiri, M. M. Aly, and S.-E. N. Ayyad, "Rare pyrane-based cembranoids from the Red Sea soft coral Sarcophyton trocheliophorum as potential antimicrobialantitumor agents," Medicinal Chemistry Research, vol. 24, no. 2, pp. 505-512, 2015.

[43] Y.-S. Kim and D.-H. Shin, "Volatile constituents from the leaves of Callicarpa japonica Thunb. and their antibacterial activities," Journal of Agricultural and Food Chemistry, vol. 52, no. 4, pp. 781-787, 2004.

[44] N. Pérez-Hernández, H. Ponce-Monter, M. I. Ortiz, R. CariñoCortés, and P. Joseph-Nathan, "Structure-activity relationships of aromadendranes in uterus-relaxant activity," Zeitschrift fur Naturforschung Section C: Journal of Biosciences, vol. 64, no. 1112, pp. 840-846, 2010.
[45] P. P. Kumar, S. Kumaravel, and C. Lalitha, "Screening of antioxidant activity, total phenolics and GC-MS study of Vitex negundo," African Journal of Biochemistry Research, vol. 4, no. 7, pp. 191-195, 2010.

[46] Y. Takao, I. Kuriyama, T. Yamada, H. Mizoguchi, H. Yoshida, and Y. Mizushina, "Antifungal properties of Japanese cedar essential oil from waste wood chips made from used sake barrels," Molecular Medicine Reports, vol. 5, no. 5, pp. 1163-1168, 2012.

[47] M. Tan, L. Zhou, Y. Huang, Y. Wang, X. Hao, and J. Wang, "Antimicrobial activity of globulol isolated from the fruits of Eucalyptus globulus Labill," Natural Product Research, vol. 22, no. 7, pp. 569-575, 2008.

[48] G. Ruberto and M. T. Baratta, "Antioxidant activity of selected essential oil components in two lipid model systems," Food Chemistry, vol. 69, no. 2, pp. 167-174, 2000.

[49] L. L. Silva, Q. I. Garlet, S. C. Benovit et al., "Sedative and anesthetic activities of the essential oils of Hyptis mutabilis (Rich) Briq. and their isolated components in silver catfish (Rhamdia quelen)," Brazilian Journal of Medical and Biological Research, vol. 46, no. 9, pp. 771-779, 2013.

[50] M. Miyazawa, H. Watanabe, K. Umemoto, and H. Kameoka, "Inhibition of acetylcholinesterase activity by essential oils of Mentha species," Journal of Agricultural and Food Chemistry, vol. 46, no. 9, pp. 3431-3434, 1998.

[51] J. M. Scher, J.-B. Speakman, J. Zapp, and H. Becker, "Bioactivity guided isolation of antifungal compounds from the liverwort Bazzania trilobata (L.) S.F. Gray," Phytochemistry, vol. 65, no. 18, pp. 2583-2588, 2004.

[52] A. Rahman, Z. Sultana Shanta, M. A. Rashid et al., "In vitro antibacterial properties of essential oil and organic extracts of Premna integrifolia Linn," Arabian Journal of Chemistry, 2011.

[53] A. Martins, Z. Hajdú, A. Vasas, B. Csupor-Löffler, J. Molnár, and J. Hohmann, "Spathulenol inhibit the human ABCB1 efflux pump," Planta Medica, vol. 76, no. 12, p. 608, 2010.

[54] L. K. Chao, K.-F. Hua, H.-Y. Hsu, S.-S. Cheng, J.-Y. Liu, and S.T. Chang, "Study on the antiinflammatory activity of essential oil from leaves of Cinnamomum osmophloeum," Journal of Agricultural and Food Chemistry, vol. 53, no. 18, pp. 7274-7278, 2005.

[55] A. Ziaei, M. Ramezani, L. Wright, C. Paetz, B. Schneider, and Z. Amirghofran, "Identification of spathulenol in Salvia mirzayanii and the immunomodulatory effects," Phytotherapy Research, vol. 25, no. 4, pp. 557-562, 2011.

[56] V. I. Babushok, P. J. Linstrom, and I. G. Zenkevich, "Retention indices for frequently reported compounds of plant essential oils," Journal of Physical and Chemical Reference Data, vol. 40, no. 4, Article ID 043101, 2011.

[57] T. Acree and H. Arn, "Flavornet," http://www.flavornet.org.

[58] D. Joulain and W. A. König, The Atlas of Spectral Data of Sesquiterpene Hydrocarbons, EB, Berlin, Germany, 1998.

[59] E. Stenhagen, S. Abrahamsson, and F. W. McLafferty, Registry of Mass Spectral Data, John Wiley \& Sons, New York, NY, USA, 1974.

[60] A. M. El Sayed, "The Pherobase: Database of Pheromones and Semiochemicals," http://www.pherobase.com/.

[61] R. P. Adams, Identification of Essential Oil Components by Gas Chromatography/Mass Spectrometry, Allured, Carol Stream, Ill, USA, 2007.

[62] National Health and Medical Research Council, Values and Ethics: Guidelines for Ethical Conduct in Aboriginal and Torres 
Strait Islander Health Research, Commonwealth of Australia, Canberra, Australia, 2003.

[63] N. Brouwer, Q. Liu, D. Harrington et al., "An ethnopharmacological study of medicinal plants in New South Wales," Molecules, vol. 10, no. 10, pp. 1252-1262, 2005.

[64] O. A. Aiyegoro and A. I. Okoh, "Preliminary phytochemical screening and in vitro antioxidant activities of the aqueous extract of Helichrysum longifolium DC," BMC Complementary and Alternative Medicine, vol. 10, article 21, 2010.

[65] P. Roy, S. Amdekar, A. Kumar, and V. Singh, "Preliminary study of the antioxidant properties of flowers and roots of Pyrostegia venusta (Ker Gawl) Miers," BMC Complementary and Alternative Medicine, vol. 11, no. 1, pp. 69-76, 2011.

[66] Y. L. Chew, E. W. L. Chan, P. L. Tan, Y. Y. Lim, J. Stanslas, and J. K. Goh, "Assessment of phytochemical content, polyphenolic composition, antioxidant and antibacterial activities of Leguminosae medicinal plants in Peninsular Malaysia," BMC Complementary and Alternative Medicine, vol. 11, article 12, 2011.

[67] M. Chaudhari and S. Mengi, "Evaluation of phytoconstituents of Terminalia arjuna for wound healing activity in rats," Phytotherapy Research, vol. 20, no. 9, pp. 799-805, 2006.

[68] F. Muanda, D. Koné, A. Dicko, R. Soulimani, and C. Younos, "Phytochemical composition and antioxidant capacity of three malian medicinal plant parts," Evidence-Based Complementary and Alternative Medicine, vol. 2011, Article ID 674320, 8 pages, 2011.

[69] T. Michel, E. Destandau, G. Le Floch, M. E. Lucchesi, and C. Elfakir, "Antimicrobial, antioxidant and phytochemical investigations of sea buckthorn (Hippophaë rhamnoides L.) leaf, stem, root and seed," Food Chemistry, vol. 131, no. 3, pp. 754-760, 2012.

[70] S.-C. Liu, J.-T. Lin, C.-K. Wang, H.-Y. Chen, and D.-J. Yang, "Antioxidant properties of various solvent extracts from lychee (Litchi chinenesis Sonn.) flowers," Food Chemistry, vol. 114, no. 2, pp. 577-581, 2009.

[71] A. A. Adedapo, F. O. Jimoh, A. J. Afolayan, and P. J. Masika, "Antioxidant activities and phenolic contents of the methanol extracts of the stems of Acokanthera oppositifolia and Adenia gummifera," BMC Complementary and Alternative Medicine, vol. 8, article 54, 2008.

[72] S.-S. Wang, D.-M. Wang, W.-J. Pu, and D.-W. Li, "Phytochemical profiles, antioxidant and antimicrobial activities of three Potentilla species," BMC Complementary and Alternative Medicine, vol. 13, no. 1, pp. 321-331, 2013.

[73] G. Appendino, S. Gibbons, A. Giana et al., "Antibacterial cannabinoids from Cannabis sativa: a structure-activity study," Journal of Natural Products, vol. 71, no. 8, pp. 1427-1430, 2008.

[74] R. J. Ruch, S.-J. Cheng, and J. E. Klaunig, "Prevention of cytotoxicity and inhibition of intercellular communication by antioxidant catechins isolated from Chinese green tea," Carcinogenesis, vol. 10, no. 6, pp. 1003-1008, 1989.

[75] S. Burapadaja and A. Bunchoo, "Antimicrobial activity of tannins from Terminalia citrina," Planta Medica, vol. 61, no. 4, pp. 365-366, 1995.

[76] H. Okamura, A. Mimura, Y. Yakou, M. Niwano, and Y. Takahara, "Antioxidant activity of tannins and flavonoids in Eucalyptus rostrata," Phytochemistry, vol. 33, no. 3, pp. 557-561, 1993.

[77] P. Navarro, R. M. Giner, M. C. Recio, S. Máñez, M. CerdáNicolás, and J.-L. Ríos, "In vivo anti-inflammatory activity of saponins from Bupleurum rotundifolium," Life Sciences, vol. 68, no. 10, pp. 1199-1206, 2001.
[78] P. Mandal, S. P. Sinha Babu, and N. C. Mandal, "Antimicrobial activity of saponins from Acacia auriculiformis," Fitoterapia, vol. 76, no. 5, pp. 462-465, 2005.

[79] T. P. T. Cushnie and A. J. Lamb, "Antimicrobial activity of flavonoids," International Journal of Antimicrobial Agents, vol. 26, no. 5, pp. 343-356, 2005.

[80] D. Amić, D. Davidović-Amić, D. Bešlo, and N. Trinajstić, "Structure-radical scavenging activity relationships of flavonoids," Croatica Chemica Acta, vol. 76, no. 1, pp. 55-61, 2003.

[81] A. L. Souto, J. F. Tavares, M. S. da Silva, M. F. F. M. de Diniz, P. F. de Athayde-Filho, and J. M. Barbosa Filho, "Anti-inflammatory activity of alkaloids: an update from 2000 to 2010," Molecules, vol. 16, no. 10, pp. 8515-8534, 2011.

[82] D. Karou, A. Savadogo, A. Canini et al., "Antibacterial activity of alkaloids from Sida acuta," African Journal of Biotechnology, vol. 4, no. 12, pp. 1452-1457, 2005.

[83] M. Frédérich, M.-J. Jacquier, P. Thépenier et al., "Antiplasmodial activity of alkaloids from various Strychnos species," Journal of Natural Products, vol. 65, no. 10, pp. 1381-1386, 2002.

[84] C. A. Rice-Evans, N. J. Miller, P. G. Bolwell, P. M. Bramley, and J. B. Pridham, "The relative antioxidant activities of plant-derived polyphenolic flavonoids," Free Radical Research, vol. 22, no. 4, pp. 375-383, 1995.

[85] A. R. Ndhlala, J. F. Finnie, and J. Van Staden, "In vitro antioxidant properties, HIV-1 reverse transcriptase and acetylcholinesterase inhibitory effects of traditional herbal preparations sold in South Africa," Molecules, vol. 15, no. 10, pp. 68886904, 2010.

[86] A. E. Hagerman, K. M. Riedl, G. A. Jones et al., "High molecular weight plant polyphenolics (Tannins) as biological antioxidants," Journal of Agricultural and Food Chemistry, vol. 46, no. 5, pp. 1887-1892, 1998.

[87] O. Stefanović, I. Radojević, L. Čomic, and S. Vasić, "Antibacterial activity of naturally occurring compounds from selected plants," in Antimicrobial Agents, InTech, Rijeka, Croatia, 2012.

[88] M. M. Cowan, "Plant products as antimicrobial agents," Clinical Microbiology Reviews, vol. 12, no. 4, pp. 564-582, 1999.

[89] H.-X. Xu and S. F. Lee, "Activity of plant flavonoids against antibiotic-resistant bacteria," Phytotherapy Research, vol. 15, no. 1, pp. 39-43, 2001.

[90] B. Havsteen, "Flavonoids, a class of natural products of high pharmacological potency," Biochemical Pharmacology, vol. 32, no. 7, pp. 1141-1148, 1983.

[91] T. Wu, M. He, X. Zang et al., "A structure-activity relationship study of flavonoids as inhibitors of $E$. coli by membrane interaction effect," Biochimica et Biophysica Acta (BBA)Biomembranes, vol. 1828, no. 11, pp. 2751-2756, 2013.

[92] H. Tsuchiya, M. Sato, T. Miyazaki et al., "Comparative study on the antibacterial activity of phytochemical flavanones against methicillin-resistant Staphylococcus aureus," Journal of Ethnopharmacology, vol. 50, no. 1, pp. 27-34, 1996.

[93] L. E. Alcaraz, S. E. Blanco, O. N. Puig, F. Tomas, and F. H. Ferretti, "Antibacterial activity of flavonoids against methicillinresistant Staphylococcus aureus strains," Journal of Theoretical Biology, vol. 205, no. 2, pp. 231-240, 2000.

[94] T. De Bruyne, L. Pieters, H. Deelstra, and A. Vlietinck, "Condensed vegetable tannins: biodiversity in structure and biological activities," Biochemical Systematics and Ecology, vol. 27, no. 4, pp. 445-459, 1999. 
[95] A. Scalbert, "Antimicrobial properties of tannins," Phytochemistry, vol. 30, no. 12, pp. 3875-3883, 1991.

[96] S. H. Lim, I. Darah, and K. Jain, "Antimicrobial activities of tannins extracted from Rhizophora apiculata barks," Journal of Tropical Forest Science, vol. 18, no. 1, pp. 59-65, 2006.

[97] G. Motalleb, P. Hanachi, S. H. Kua, O. Fauziah, and R. Asmah, "Evaluation of phenolic content and total antioxidant activity in Berberis vulgaris fruit extract," Journal of Biological Sciences, vol. 5, no. 5, pp. 648-653, 2005.

[98] J. L. Ríos and M. C. Recio, "Medicinal plants and antimicrobial activity," Journal of Ethnopharmacology, vol. 100, no. 1-2, pp. 8084, 2005.

[99] H. B. Q. Tran, J. M. McRae, F. Lynch, and E. A. Palombo, "Identification and bioactive properties of endophytic fungi isolated from phyllodes of Acacia species," in Current Research, Technology and Education Topics in Applied Microbiology and Microbial Biotechnology, pp. 377-382, Formatex, Madrid, Spain, 2010.

[100] R. Wang, R. Wang, and B. Yang, "Extraction of essential oils from five cinnamon leaves and identification of their volatile compound compositions," Innovative Food Science and Emerging Technologies, vol. 10, no. 2, pp. 289-292, 2009. 


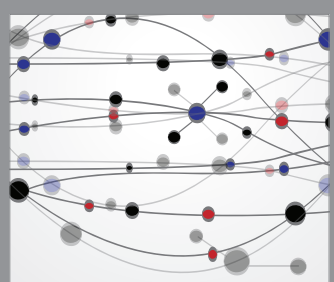

The Scientific World Journal
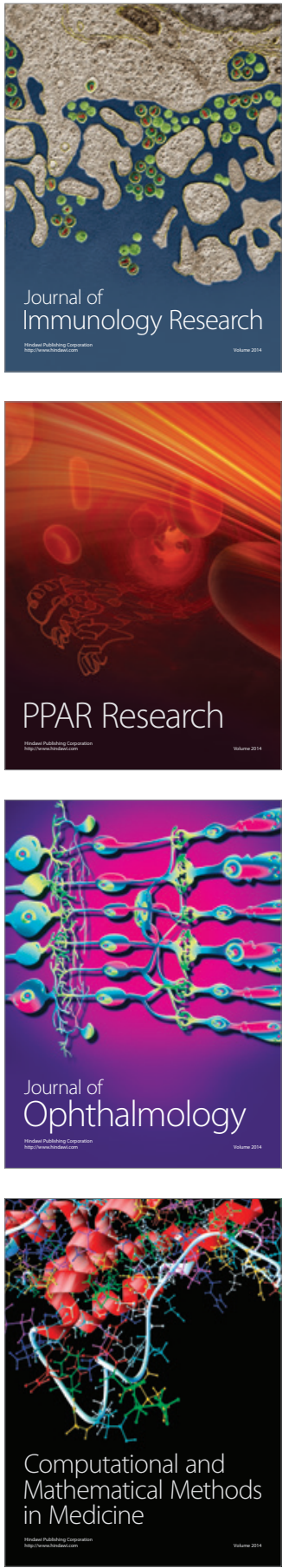

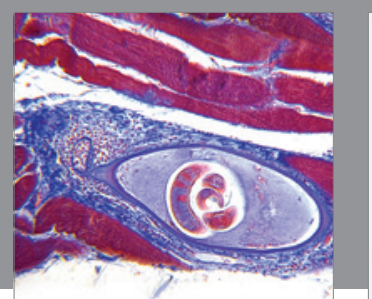

Gastroenterology Research and Practice

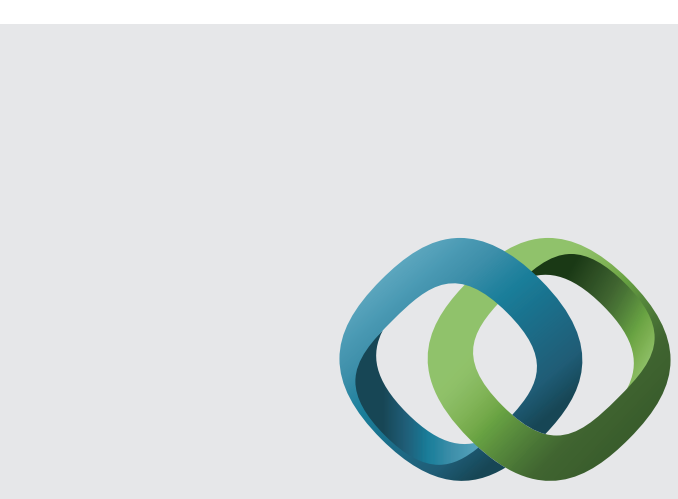

\section{Hindawi}

Submit your manuscripts at

http://www.hindawi.com
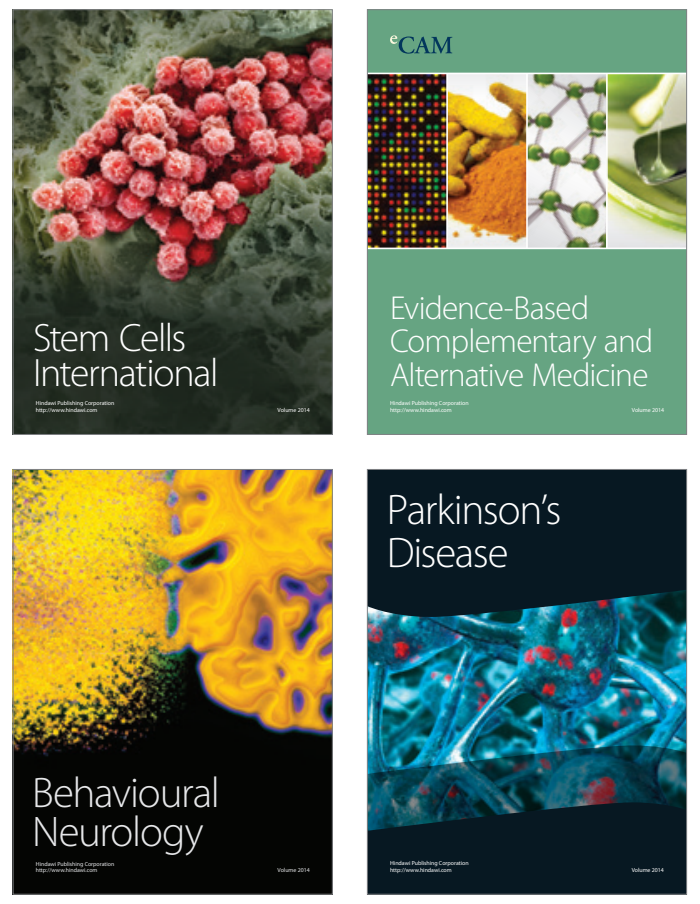
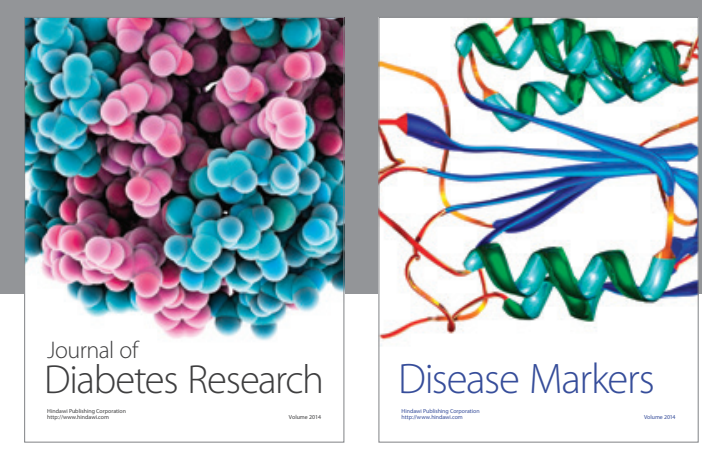

Disease Markers
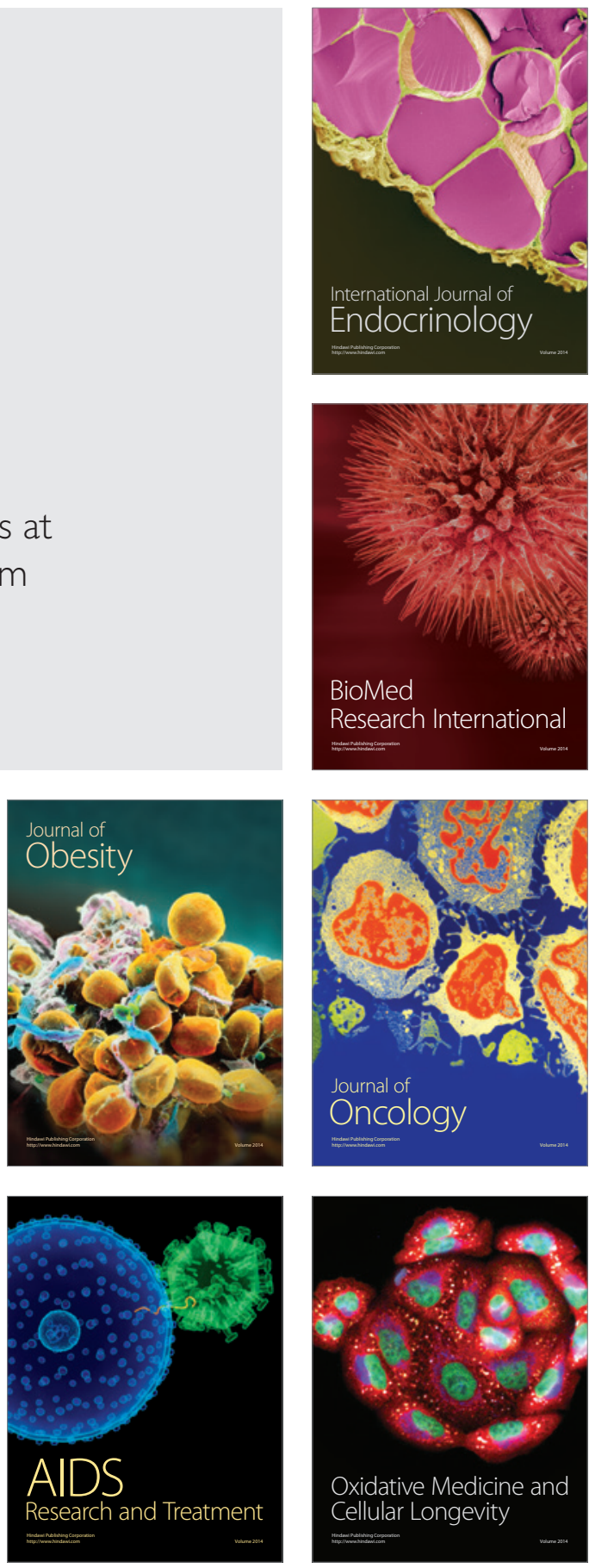